\title{
RADIOCARBON DATES FROM AMERICAN SAMOA
}

\author{
JEFFREY T. CLARK
}

Department of Sociology-Anthropology, North Dakota State University P.O. Box 5075, Fargo, North Dakota 58105 USA

ABSTRACT. Between 1988 and 1991, I directed five archaeological research projects in American Samoa. The goal of that research was to reveal changes in the prehistoric settlement system of Samoa, from initial colonization of the archipelago to the time of significant European contact. The chronological placement of key sites was an essential facet of the research. A secondary goal was to locate sites with ceramic components, particularly sites with Lapita ceramics, and relate the ceramic assemblages typologically and chronologically to those known for Western Samoa. These investigations generated $16{ }^{14} \mathrm{C}$ dates from archaeological contexts. I present here the previously unpublished ${ }^{14} \mathrm{C}$ data from those samples, and briefly summarize their importance for understanding Samoan prehistory.

\section{INTRODUCTION}

The Samoan Archipelago lies in the central South Pacific Ocean $\left(168^{\circ}-173^{\circ} \mathrm{W}, 13^{\circ}-15^{\circ} \mathrm{S}\right)$, and with the neighboring Tonga Archipelago, constituted the prehistoric western "gateway" to Polynesia. Consequently, both archipelagoes are extremely important for understanding the prehistory of central and eastern Oceania.

The large western islands of 'Upolu and Savai'i, along with the small islands of Manono and Apolima, constitute the independent nation of Western Samoa (Fig. 1). The eastern islands of the archipelago compose American Samoa, a USA territory. Tutuila, the largest island of the group, and the small neighboring island of Aunu'u form a western subgroup, whereas the islands of Ta'u, Ofu and Olosega form an eastern subgroup, Manu'a.

In the late 1960s and early 1970s, Green and Davidson $(1969,1974)$ conducted extensive and highly informative archaeological research in Western Samoa. In the mid-to-late 1970s, Jennings et al. (1976) and Jennings and Holmer (1980) directed additional investigations in Western Samoa. Little research has been done on the island nation since that time. In American Samoa, Kikuchi (1963) compiled a site inventory based on extensive interviews and some survey, Frost (1978) conducted limited test excavations at seven sites, and others carried out a few small surveys (Clark 1980, 1981; Ladd \& Morris 1970; Kikuchi et al. 1975; Silva \& Palama 1975; McCoy 1977). Since 1985 , several archaeological projects have been conducted in the territory, substantially expanding our knowledge of the area (e.g., Ayres \& Eisler 1987; Best, Leach \& Witter 1989; Clark \& Herdrich 1988, 1993; Clark 1989, 1990, 1992; Gould, Honor \& Reinhardt 1985; Hunt \& Kirch 1988; Kirch et al. 1990; Leach \& Witter 1987, 1990).

As a result of these projects, numerous ceramic sites have been found in the archipelago. Only Mulifanua on the west coast of 'Upolu Island yielded pottery of the distinctive Lapita type. The Mulifanua site is submerged and was discovered by dredging for a ferry harbor. $\mathrm{A}^{14} \mathrm{C}$ date (NZ1958) from shell in a coralline crust containing and overlying potsherds provided a calibrated age, based on Pearson and Stuiver (1986), of 3399-2779 cal BP at one sigma (1б) (Leach \& Green 1989:319). All other sites have yielded only Plain Ware and have been interpreted as dating to later than the Lapita site.

Based on the early work in Western Samoa, Green (1974a, b) summarized data on the portable artifact sequence for Samoan prehistory. In that proposed sequence, which is now widely accepted, the islands were settled over 3000 years ago by people making Lapita pottery. 


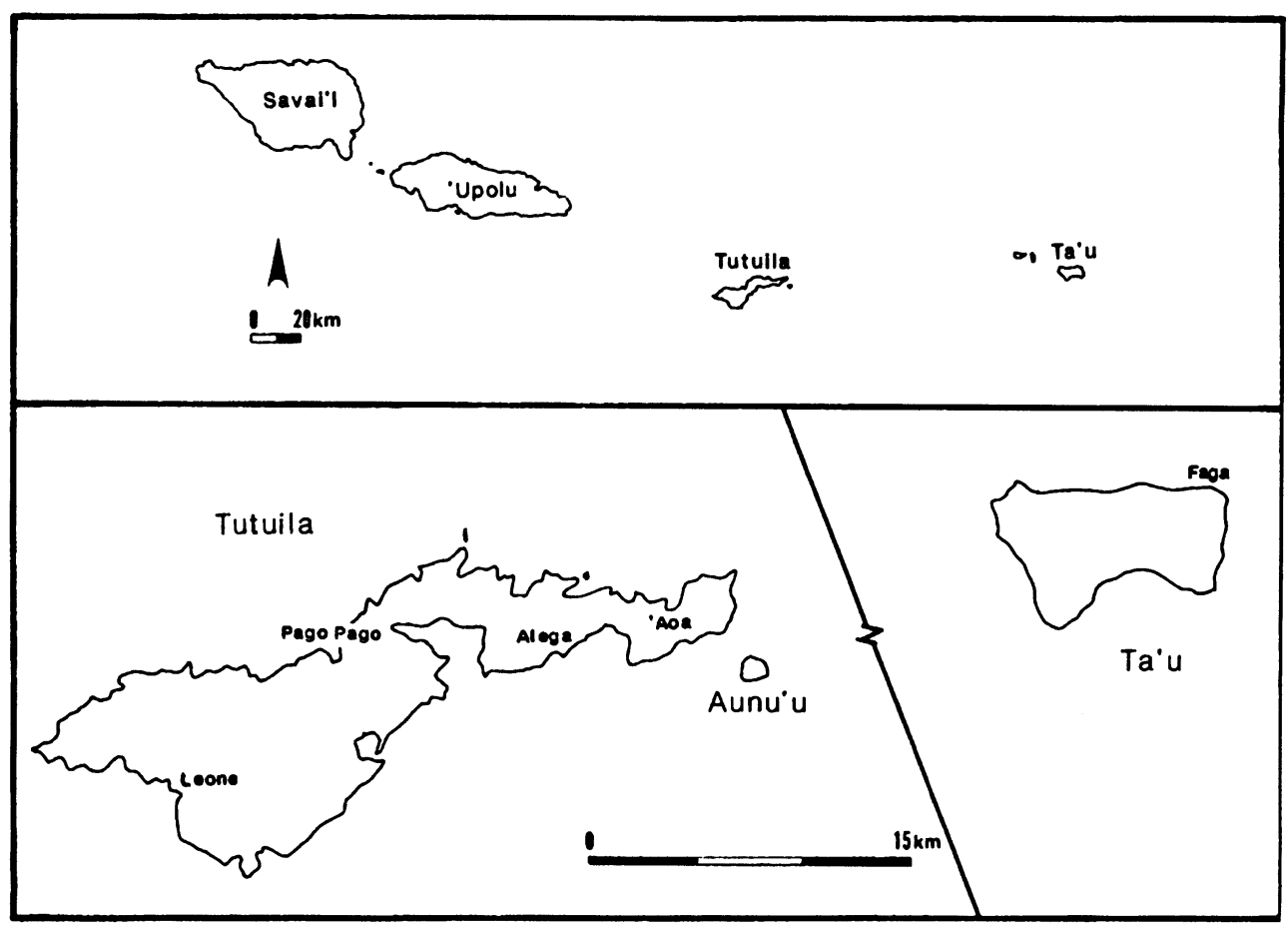

Fig. 1. The major islands of the Samoan Archipelago with enlargements of Tutuila and Ta'u Islands

Eventually, Samoan Plain Ware developed from Lapita and went through two stages: an early thin, fine-tempered ware and a later thick, coarse-tempered ware. Pottery-making ended in Samoa between $c a$. AD 200 and 600, as it did in nearby Tonga. Though no new Lapita sites were discovered in subsequent research, an assumption remains that such sites are present but are yet to be found. Some of the dates presented here, however, alter this picture of Samoan prehistory.

\section{DATA AND DISCUSSION}

The ${ }^{14} \mathrm{C}$ ages reported here were determined by Beta Analytic, Inc. (Miami, Florida, USA) from samples of charcoal collected from four areas of American Samoa. The samples were air-dried in Samoa; most underwent preliminary cleaning at the Archaeology Lab at North Dakota State University, Fargo. At Beta Analytic, samples were given standard pretreatment. They were examined for rootlets, and then underwent acid-base-acid treatment. This was followed by benzene syntheses and counting, but, in several cases, the small carbon content necessitated extended counting time. $\delta^{13} \mathrm{C}$ was measured for only ten samples. The ${ }^{14} \mathrm{C}$ ages were calibrated according to ATM20.14C (Pearson \& Stuiver 1986; Stuiver \& Pearson 1986). The calibrated dates are presented at $2 \sigma$, as this provides the most reliable calculation. Dates are corrected for fractionation where $\delta^{13} \mathrm{C}$ measurements are reported below.

Excavations at three valleys on Tutuila generated 15 of the dates below. Most of these (8) came from a single site, AS-21-5 Locality 2, in 'Aoa Valley on the northeast coast (Fig. 1). Additional dates came from limited excavations at Alega Valley on the south coast of west-central Tutuila, and from Leone on the south coast of western Tutuila. A final ${ }^{14} \mathrm{C}$ age is from a site at Faga on the northeast coast of Ta'u Island. 
The excavations at 'Aoa Valley were conducted in three phases; the last and most extensive of these has not yet been reported (Clark \& Herdrich 1988, 1993; Clark 1989). Site AS-21-5, Locality 2 , is in the eastern portion of the valley, about $220 \mathrm{~m}$ from the shoreline, near the taluvial slope that backs the valley. The investigations revealed two ceramic components, both buried under alluvial and colluvial deposits. The early component is pottery-rich, obsidian-rich, and basalt-poor, and is contemporaneous with the Lapita site of Mulifanua, starting at $c a .3000$ BP. However, no sherds show any decoration. The late component dates to $c a$. 500-300 BP, which is $c a .1000 \mathrm{yr}$ later than the conventionally accepted abandonment of ceramics in Samoa. This artifact assemblage is pottery-poor, obsidian-poor, and basalt-rich. Again, no sherds are decorated.

The ${ }^{14} \mathrm{C}$-dated samples from Leone came from a series of test pits distributed through Leone Valley. Surprisingly, all are comparatively late, after $1000 \mathrm{BP}$. Each of the dated sites falls into the extended period of ceramic use shown at 'Aoa, yet no ceramics were found in any excavations. A few sherds were found in the valley and surrounding ridges, but not in securely dated contexts (Best, Leach \& Witter 1989; Clark 1980, 1981).

Both Alega Valley dates are from a terrace constructed at the rear of the small valley to create a surface for manufacturing stone tools. The dates mark the beginning of terrace use, probably $c a$. 600 BP (Clark 1992). This probably corresponds generally to the onset of exploitation of one or more of the three basalt quarries on the ridge slopes a short distance above the terrace. I recovered no ceramics from the limited test excavations, but found a few surface sherds at the nearest quarry.

The single date from Ta'u Island reflects occupation beginning ca. 800-900 BP on a portion of the large coastal flat of Faga (Clark 1990). This area developed through localized coastal progradation during the last millennium, and the site area on the surrounding alluvial and taluvial land is probably older, perhaps significantly. No ceramics were recovered from the single excavation unit at the site.

\section{CONCLUSIONS}

Five conclusions can be drawn from the archaeological sites and dates discussed here:

1. Site AS-21-5 at 'Aoa is the oldest reported site in American Samoa. As artifacts were recovered from beneath the dated charcoal sample, the date of initial occupation at the site is sometime prior to the age assessment of Beta-48049 (3389 cal BP (3006) 2749 at $2 \sigma$ ).

2. Lapita occupation in the Samoan archipelago, as identified by the presence of the distinctive dentate-stamped and incised pottery, was quite limited. Given the number of archaeological investigations that have now been carried out in the archipelago, several with the intent of finding Lapita sites, the absence of such sites beyond Mulifanua is striking and probably meaningful. Of the possible explanations for this situation, only two will be mentioned here.

First, this easternmost extension of Lapita may be represented by ceramic assemblages in which the distinctive decorations were rarely applied, and were abandoned soon after island settlement in favor of a derived Samoan Plain Ware. Decorated sherds at Lapita sites elsewhere typically compose only a small percentage of the total assemblage, often under $10 \%$. Therefore, a complete abandonment of decorations would not be a decidedly dramatic change. Some time ago, Green (1974b) proposed such a shift from decorated Lapita to Samoan Plain Ware, but the data discussed here suggest that the shift was sooner than previously suspected. 
Second, it may be that the Mulifanua site was not occupied by "Lapita people," and the small percentage of decorated Lapita ceramics at the site represent trade ware from outside the archipelago (see Terrell 1989). This would suggest a contemporaneous non-Lapita occupation of Samoa, perhaps reflecting a widespread Plain Ware tradition and associated culture(s). Plain Ware sites have been reported from throughout the central Pacific, although the precise relation of Plain Ware to the Lapita tradition has not been firmly established.

3. The late component at 'Aoa suggests that pottery was used in Samoa for $c a .1000 \mathrm{yr}$ after the supposed abandonment of ceramics. Other sites, e.g., Alega, with sherds at an associated late quarry, provide some support for this suggestion, but none so clearly as 'Aoa. This late component is represented by Layers II-V (rapid sediment deposition due to landscape instability), where five reliable dates (a sixth date is probably contaminated) indicate the 15 th century AD.

4. The absence of pottery from other sites contemporary with the late ceramic component, e.g., at Leone and Faga, suggests that pottery was not abandoned uniformly and completely throughout the archipelago, but differentially, with some sites or areas manufacturing ceramics substantially longer than others, and perhaps some sites securing small quantities of ceramics through trade. The fact that the Leone area was a center of basalt production for trade suggests, however weakly, the possibility of regional specialization on Tutuila.

5. The ten $\delta^{13} \mathrm{C}$ measurements listed below range between $-24.4 \%$ and $-28.8 \%$, and average $-27.32 \%$. When $18 \delta^{13} \mathrm{C}$ measurements are added, all from charcoal samples from other studies, the range shifts to $-24.4 \%$ to $-29.68 \%$ and the mean shifts slightly to $-27.45 \% 0$ (Ayres, personal communication; Kirch, Hunt \& Tyler 1989; Leach \& Witter 1990; DSIR Institute of Nuclear Sciences, New Zealand, correspondence, 1992). While it is possible that some dated charcoal samples may be from plants with photosynthetic pathways that would yield a very different ${ }^{13} \mathrm{C}$ value, none of the dated charcoal samples from Samoa with measured $\delta^{13} \mathrm{C}$ showed widely divergent values. Thus, it seems reasonable to assume a $\delta^{13} \mathrm{C}$ of $-27 \%$ for adjusting ages on charcoal which were not $\delta^{13} \mathrm{C}$ measured, or to estimate an adjustment of $-30 \mathrm{yr}$ for such ages. Such a correction should improve the age assessments of most, if not all, of the samples lacking $\delta^{13} \mathrm{C}$ values. Regardless of the precise adjustment for ${ }^{13} \mathrm{C}$, the ${ }^{14} \mathrm{C}$ ages shift comparatively little and the broad picture of Samoan prehistory is unaltered.

The $16{ }^{14} \mathrm{C}$ dates presented here demonstrate that previous interpretations of Samoan prehistory may be flawed due to limited data. Additional research is needed in all parts of Samoa, and a reevaluation of previously reported chronological data is needed to clarify critical issues in the prehistory of central Oceania.

\section{ACKNOWLEDGMENTS}

The archaeological projects that produced the dates reported here were funded by the National Science Foundation, Grant No. 9111566; the Historic Preservation Office, Department of Parks and Recreation, American Samoa Government, Pago Pago; G. M. Meredith and Associates, Apia, Western Samoa; McConnell Dowell Constructors, Ltd., Sydney; and North Dakota State University, Fargo. I extend my appreciation to all those people, far too numerous to list, who assisted me in these projects with funding, administration, fieldwork and lab analyses. Special thanks, however, are extended to Michael Michlovic, Erik Pearthree, David Herdrich, Scott Dundelberger and Todd Clark for their assistance in collecting and processing these samples. 


\section{ARCHAEOLOGICAL SAMPLES}

\section{'Aoa Valley, Tutuila Island}

Beta-28210. 'Aoa, Tutuila

Charcoal, Site AS-21-5, Locality 2, Unit 4, stream bank, Layer II, Feature 1, dark charcoalstained basin, 113-123 cm below surface, (field sample 88RC1). Cal AD $1453(1519,1587,1623)$ 1651 at $2 \sigma ; 497$ cal BP $(431,363,327) 299$ at $2 \sigma$.

Comment: This layer is part of the late ceramic component.

Beta-28211. 'Aoa, Tutuila

$350 \pm 50$

Charcoal pieces, Site AS-21-5, Locality 2, Unit 4, stream bank, Layer V, 150-160 cm below surface, from a small band in upper portion of layer, charcoal pieces abundant and large sample submitted (field sample 88RC2). Cal AD 1440 (1506) 1650 at $2 \sigma ; 510 \mathrm{cal} \mathrm{BP} \mathrm{(444)} 300$ at $2 \sigma$.

Comment: This layer is part of the late ceramic component.

Beta-28212. 'Aoa, Tutuila

$170 \pm 40$

Charcoal pieces, Site AS-21-5, Locality 2, Unit 4, stream bank, Layer V, Feature 9, 160-165 $\mathrm{cm}$ below surface, collected from soil in upper area of fireplace (field sample 88RC3). Cal AD $1650(1676,1747,1799,1942,1955) 1955$ at $2 \sigma ; 300 \mathrm{cal} \mathrm{BP}(274,203,151,8,0) 0$ at $2 \sigma$.

Comment: An area of apparent disturbance, possibly due to land crabs, is within $20 \mathrm{~cm}$ of the feature. The disturbance conceivably extended to the fireplace area, though not recognized during excavation, which could account for the unusually young age of the sample. This date should be rejected due to probable contamination. This layer is part of the late ceramic component.

Beta-48047. 'Aoa, Tutuila

$400 \pm 80$ $\delta^{13} \mathrm{C}=-2.70 \%$

Charcoal, Site AS-21-5, Locality 2, stream bank profile, Layer V, 140-156 cm below surface, collected from small area of concentration, ceramic layer (field sample A-8). Cal AD 1400 (1460) 1650 at $2 \sigma ; 550 \mathrm{cal} \mathrm{BP}(490) 300$ at $2 \sigma$.

Comment: This layer is part of the late ceramic component.

Beta-48048. 'Aoa, Tutuila

$470 \pm 60$

$\delta^{13} \mathrm{C}=-28.0 \%$

Charcoal pieces, Site AS-21-5, Locality 2, Unit 5, Layer V, 84-94 cm below surface, scattered through 10-cm-thick level, ceramic layer (field sample A-9). Cal AD 1321 (1434) 1611 at $2 \sigma ; 629$ cal BP (516) 339 at $2 \sigma$.

Comment: This layer is part of the late ceramic component.

Beta-48049. 'Aoa, Tutuila

$2890 \pm 140$

$\delta^{13} \mathrm{C}=-28.2 \%$

Charcoal, Site AS-21-5, Locality 2, Unit 7, Layer VII, $c a$. $170 \mathrm{~cm}$ below surface, scattered pieces, small sample $(0.22 \mathrm{~g})$ given extended counting time (four times normal amount), ceramic 
layer, deepest sample collected from site (field sample A-10). Cal BC 1440 (1057) 800 at 2 o; 3389 cal BP (3006) 2749 at $2 \sigma$.

Comment: This layer represents the early ceramic component. Artifacts were recovered in comparatively small numbers from below this dated sample.

Beta-48910. 'Aoa, Tutuila

$510 \pm 70$

$\delta^{13} \mathrm{C}=-26.9 \%$

Charcoal pieces, Site AS-21-5, Locality 2, Stream Bank Profile, Layer II, scattered through layer, small sample $(0.46 \mathrm{~g})$ given extended counting time (four times normal amount) (field sample A-7). Cal AD 1290 (1418) 1443 at $2 \sigma ; 660$ cal BP (532) 470 at $2 \sigma$.

Comment: This layer is part of the late ceramic component.

\section{Beta-48911. 'Aoa, Tutuila}

Charcoal pieces, Site AS-21-5, Locality 2, Unit 8, Layer VII, 128-148 cm below surface, scattered in small area of unit, small sample $(0.32 \mathrm{~g})$ given extended counting time (four times normal amount) (field sample A-12). Cal BC $830(755,698,537) 370$ at $2 \sigma ; 2779$ cal BP (2704, 2647, 2486) 2319 at $2 \sigma$.

Comment: This layer represents the early ceramic component. The date agrees with the older and more deeply buried sample, Beta-48049, above.

Leone Valley, Tutuila Island

\section{Beta-48051. Leone, Tutuila}

$$
\delta^{13} C=\begin{array}{r}
520 \pm 60 \\
-26.5 \% 0
\end{array}
$$

Charcoal, Site AS-34-38, Test Pit 5, Layer IX, 200-220 cm below surface, scattered pieces collected throughout 20-cm-thick layer (field sample L-3). Cal AD 1290 (1414) 1460 at 2 \%; 660 cal BP (536) 490 at $2 \sigma$.

Comment: This is a lower valley site and the excavation unit is located $37 \mathrm{~m}$ from the coastline. Beta-48913, below, from $100-110 \mathrm{~cm}$, is younger than this sample.

Beta-48052. Leone, Tutuila

$780 \pm 70$

$\delta^{13} \mathrm{C}=-28.1 \%$ 。

Charcoal pieces, Site AS-34-44, Test Pit 9, Layer I, 90-100 cm below surface, scattered through 10-cm-thick level (field sample L-4). Cal AD 1047 (1259) 1290 at 2 o; 903 cal BP (691) 660 at $2 \sigma$.

Comment: This is an upper valley site; the excavation unit is $c a .661 \mathrm{~m}$ from the coastline.

\section{Beta-48912. Leone, Tutuila0}

$930 \pm 80$

$$
\delta^{13} \mathrm{C}=-28.8 \% 0
$$

Charcoal, Site AS-34-45, Test Pit 6, Layer V, level 9, 85-90 cm below surface, small concentration of charcoal, small sample $(0.61 \mathrm{~g})$ given extended counting time (four times normal amount) (field sample L-1). Cal AD $970(1043,1105,1112,1150) 1210$ at 2 б; 980 cal BP $(907,845,838$, 800) 690 at $2 \sigma$. 
Comment: This is a middle valley site; the excavation unit is $c a .302 \mathrm{~m}$ from the coastline.

\section{Beta-48913. Leone, Tutuila}

$$
\delta^{13} C=\begin{array}{r}
340 \pm 80 \\
-26.5 \%
\end{array}
$$

Charcoal, Site AS-34-38, Test Pit 5, Layer VII, level 11, 100-110 cm below surface, scattered pieces (field sample L-2). Cal AD $1420(1514,1600,1616) 1955$ at $2 \sigma ; 530$ cal BP $(436,350,334)$ 0 at $2 \sigma$.

Comment: This age determination, which is from a unit in the lower valley some $37 \mathrm{~m}$ from the coastline, agrees with the deeper sample, Beta-48051, above.

\section{Beta-48915. Leone, Tutuila}

$$
\delta^{13} C=\begin{array}{r}
280 \pm 60 \\
-28.8 \%
\end{array}
$$

Charcoal, Site AS-34-40, Test Pit 3, Layer II, level 4, 30-40 cm below surface, small scatter of charcoal, small sample $(0.70 \mathrm{~g})$ given extended counting time (four times normal amount) (field sample L-6). Cal AD 1460 (1642) 1660 at $2 \sigma ; 490 \mathrm{cal} \mathrm{BP} \mathrm{(308)} 0$ at $2 \sigma$.

Comment: This site is on a small raised area in the midst of a mangrove swamp of the inner bay at Leone.

\section{Alega Valley, Tutuila Island}

\section{Beta-38438. Alega, Tutuila}

$1040 \pm 230$

Charcoal, Site AS-23-21, Unit 1, base Layer I/top Layer II, small pieces of scattered charcoal, small sample $(0.16 \mathrm{~g})$ given extended counting time (two times normal amount) (field sample RC Al-1). Cal AD 560 (999) 1395 at $2 \sigma ; 1390 \mathrm{cal} \mathrm{BP}$ (951) 555 at $2 \sigma$.

Comment: The sample was collected at the interface of Layers I and II, at $c a .30-40 \mathrm{~cm}$ below surface. Layer I represents terrace fill over subsoil of Layer II; thus, the date marks the start of terrace use. The unit is $c a .153 \mathrm{~m}$ from the coastline.

Beta-38753. Alega, Tutuila

$590 \pm 70$

Charcoal, Site AS-23-21, Units 2 \& 4, top Layer II/base Layer I, scattered pieces collected from band $c a .6 \mathrm{~cm}$ thick at layer interface, $c a .30-40 \mathrm{~cm}$ below surface (field sample RC Al-2). Cal $\mathrm{AD} 1270(1322,1340,1392) 1440$ at $2 \sigma ; 680 \mathrm{cal} \mathrm{BP}(628,610,558) 510$ at $2 \sigma$.

Comment: This date also marks initial terrace use. The unit is $c a .152 \mathrm{~m}$ from the coastline.

\section{Faga Coastal Flat, Ta'u Island}

\section{Beta-38752. Faga, Ta'u}

$910 \pm 80$

Charcoal, Site AS-11-1, Unit 1, Layer VII, $130-136 \mathrm{~cm}$ below surface, from a layer of sand underlying a house floor (field sample RC T-1). Cal AD $980(1058,1078,1125,1136,1156) 1270$ at $2 \sigma ; 970 \mathrm{cal} \mathrm{BP}(892,872,825,814,794) 680$ at $2 \sigma$.

Comment: The unit is $c a .50 \mathrm{~m}$ from the coastline. This date probably reflects the approximate time of the earliest use of this portion of the coastal flat, but slightly higher ground immediately surrounding this low area may have been occupied earlier. 


\section{REFERENCES}

Ayres, W. S. and Eisler, D. (ms.) 1987 Archaeological survey in westem Tutuila: A report on archaeological site survey and excavations (85-2). Report on file, Historic Preservation Office, American Samoa Govemment, Pago Pago.

Best, S., Leach, H. M. and Witter, D. C. 1989 Report on the second phase of fieldwork at the Tataga-matau site, American Samoa, July-August 1988. Working Papers in Anthropology, Archaeology, Linguistics, Maori Studies 83. Department of Anthropology, University of Auckland, New Zealand.

Clark, J. T. (ms.) 1980 Historic preservation in American Samoa: Program evaluation and archaeological site inventory. Report on file, Historic Preservation Office, American Samoa Govemment, Pago Pago.

1981 Archaeology in American Samoa. In Atlas of American Samoa. U.S. Office of Coastal Zone Management, the American Samoa Government, and the Department of Geography, University of Hawaii, Honolulu.

(ms.) 1989 The eastem Tutuila archaeological project: 1988 final report. Report on file, Historic Preservation Office, American Samoa Government, Pago Pago.

(ms.) 1990 The Ta'u Road archaeological project. Report on file, Historic Preservation Office, American Samoa Government, Pago Pago.

(ms.) 1992 The archaeology of Alega Valley: Residence and small industry in prehistoric Samoa. Report on file, Historic Preservation Office, American Samoa Government, Pago Pago.

Clark, J. T. and Herdrich, D. J. (ms.) 1988 The eastern Tutuila Archaeological project: 1986 final report. Report on file, Historic Preservation Office, American Samoa Government, Pago Pago.

1993 Prehistoric settlement system in eastern Tutuila, American Samoa. Journal of the Polynesian Society 102, in press.

Frost, J. (ms.) 1978 Archaeological Investigations on Tutuila Island, American Samoa. Ph.D dissertation, Department of Anthropology, University of Oregon, Eugene.

Gould, R. A., Honor, K. E. and Reinhardt, K. J. (ms.) 1985 Final project report for Tulauta and Fagatele Bay prehistoric villages and Leone Bay petroglyphs. Report on file, Historic Preservation Office, American Samoa Government, Pago Pago.

Green, R. C. 1974a Excavations of the prehistoric occupations of SU-Sa-3. In Green, R. C. and Davidson, J. M., eds, Archaeology in Western Samoa, Vol. II. Bulletin of the Auckland Institute and Museum 7: 108-154.

1974b A review of portable artifacts from Westem Samoa. In Green, R. C. and Davidson, J. M., eds, Archaeology in Western Samoa, Vol. II. Bulletin of the Auckland Institute and Museum 7: 245-275.

Green, R. C. and Davidson, J. M, eds. 1969 Archaeology in Westem Samoa, Vol. I. Bulletin of the Auckland Institute and Museum 6

1974 Archaeology in Western Samoa, Vol. II. Bulletin of the Auckland Institute and Museum 7.
Hunt, T. L. and Kirch P. V. 1988 An archaeological survey of the Manu'a Islands, American Samoa. Journal of the Polynesian Society 97(2): 153-183.

Jennings, J. D. and Holmer, R. N. 1980 Archaeological excavations in Westem Samoa. Pacific Anthropological Records 32, B.P. Bishop Museum, Honolulu.

Jennings, J. D., Holmer, R. N., Janetski, J. and Smith, H. L 1976 Excavations on Upolu, Western Samoa. Pacific Anthropological Records 25, B.P. Bishop Museum, Honolulu.

Kikuchi, W. K. (ms.) 1963 Archaeological Surface Ruins in American Samoa. Unpublished M.A. thesis, Department of Anthropology, University of Hawaii, Honolulu.

Kikuchi, W. K, Palama, S. L. and Silva, T. E. (ms.) 1975 Archaeological reconnaissance survey proposed Ta'u Harbor at Fusi and quarry site between Fusi and Fagamoto Ta'u Island, Manu'a Group, American Samoa. Report on file, Department of Anthropology, B.P. Bishop Museum, Honolulu.

Kirch, P. V., Hunt, T. L, Nagaoka, L. and Tyler, J. 1990 An ancestral Polynesian occupation site at To'aga, Ofu Island, American Samoa. Archaeology in Oceania 25(1): 1-15.

Kirch, P. V., Hunt, T. L and Tyler, J. 1989 A radiocarbon sequence from the To'aga site, Ofu Island, American Samoa. Radiocarbon 31(1): 7-13.

Ladd, E. J. and Morris, D. K. (ms.) 1970 Archaeological and ecological survey of 'Olovalu Crater, Island of Tutuila, American Samoa. Report on file, National Park Service, Washington, D.C.

Leach, H. M. and Green, R. C. 1989 New information for the Ferry Berth site, Mulifanua, Western Samoa. Journal of the Polynesian Society 98: 319-329.

Leach, H. M. and Witter, D. C. 1987 Tataga-matau 'rediscovered'. New Zealand Journal of Archaeology 9: 33-54.

1990 Further investigations at the Tataga-matau site, American Samoa. New Zealand Journal of Archaeology 12: 51-83.

McCoy, P. (ms.) 1977 Cultural reconnaissance survey 'Au'asi harbor project 'Au'asi, Tutuila Island, American Samoa. Report on file, Department of Anthropology, B.P. Bishop Museum, Honolulu.

Pearson, G. W. and Stuiver, M. 1986 High-precision calibration of the radiocarbon time scale, 500-2500 BC. In Stuiver, M and $\mathrm{Kra}, \mathrm{R}$. S., eds., Proceedings of the 12th International ${ }^{14} \mathrm{C}$ Conference. Radiocarbon 28(2B): 839-862.

Silva, T. E. and Palama, S. L. (ms.) 1975 Archaeological reconnaissance survey proposed shoreline and highway improvements, Tutuila Island, and Aunu'u Boat Harbor, Aunu'u Island, American Samoa. Report on file, U.S Army Corps of Engineers, Honolulu.

Stuiver, M. and Pearson, G. W. 1986 High-precision calibration of the radiocarbon time scale, AD 1950-500 BC. In Stuiver, M. and Kra, R. S., eds., Proceedings of the 12th International ${ }^{14} \mathrm{C}$ Conference. Radiocarbon 28(2B): 805-838.

Terrell, J. 1989 Commentary: What Lapita is and what Lapita isn't. Antiquity 63: 623-626. 